\title{
On the Supply of, and Demand for, U.S. Treasury Debt
}

David Andolfatto, Vice President and Economist

Andrew Spewak, Senior Research Associate

T hroughout the early 2000s, federal debt held by the public-the amount of outstanding U.S. Treasury securities (Treasuries) held by the Federal Reserve System and private investors-was stable at around 35 percent of gross domestic product (GDP). Since the financial crisis of 2007-08, however, the federal debt has grown significantly. As of 2017:Q4, debt held by the public was 75 percent of GDP.

Whenever the supply of an object increases, economic theory suggests that-all else equal-its price can be expected to drop. Using this logic, the large increase in the supply of Treasury debt should have caused bond prices to fall-that is, bond yields to rise. In fact, the exact opposite transpired: Treasury bond yields fell (bond prices rose) dramatically and persistently. For example, a 10-year nominal Treasury bond yielded 2.9 percent per annum as of February 2018, about half the pre-crisis interest rate in mid-2007. Is economic theory wrong?

Demand for Treasuries increased during and after the financial crisis, but may be slowing.

Not necessarily. The key qualifier in the prediction is all else equal - that is, assuming that all else remains unchanged. In fact, evidence suggests that the demand for Treasury debt was growing at the same time. Indeed, one way to interpret the evidence is that the demand for Treasury debt grew more rapidly than its supply (as evidenced by very low bond yields, for example). What was the source of this elevated demand for Treasury debt?

The increased demand for Treasuries has taken place throughout the domestic economy and global economies. As shown in Figure 1, ownership of Treasuries has spiked in several sectors since the start of the crisis. As one might expect, the reasons behind these increases are also quite diverse. In this essay, we take a closer look at some of the various factors that have caused this increased demand for Treasuries throughout the domestic economy and global economies.

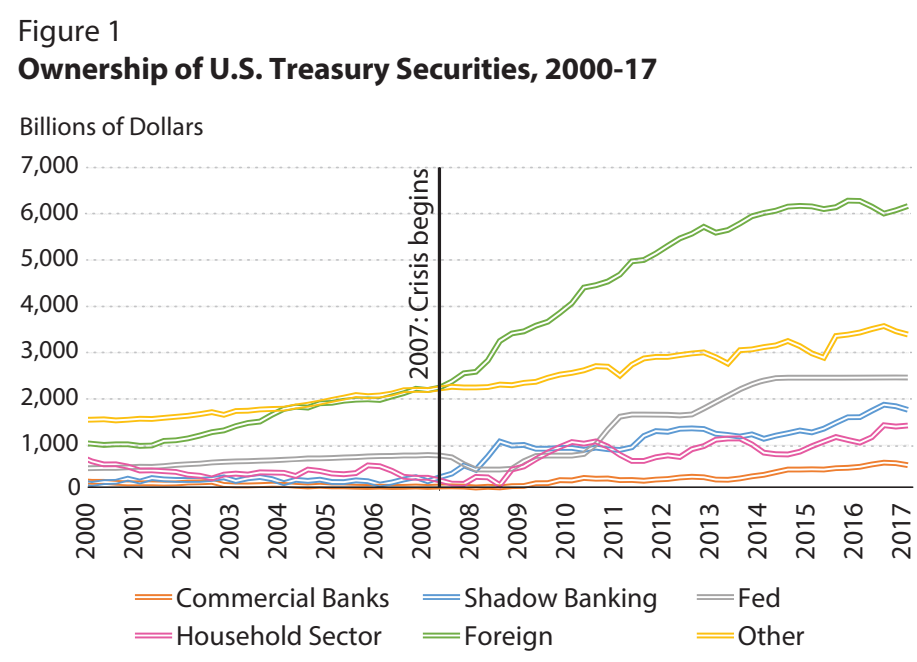

SOURCE: Board of Governors of the Federal Reserve System.

Figure 2

Foreign Holders of U.S. Treasury Securities, 2000-17

Billions of Dollars

2,500

2,000

1,500

1,000

500

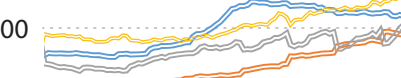

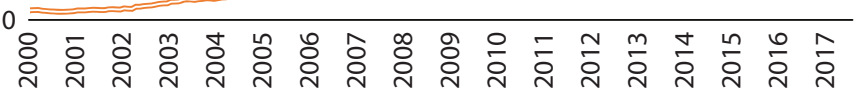

=China (Mainland) =Japan =Europe = Other

SOURCE: U.S. Department of the Treasury.

\section{Treasuries as Safe Assets}

As financial instability increases, investors replace risky assets with high-quality, safe ones in a so-called "flight to quality." Treasuries are widely considered to be among the safest assets in the world, so investors tend to invest in them during times of uncertainty. Thus, during the 2007-08 crisis, demand for Treasuries increased in 
Figure 3

Commercial Bank Treasury Security Holdings to

Private-sector Loans, 2000-17

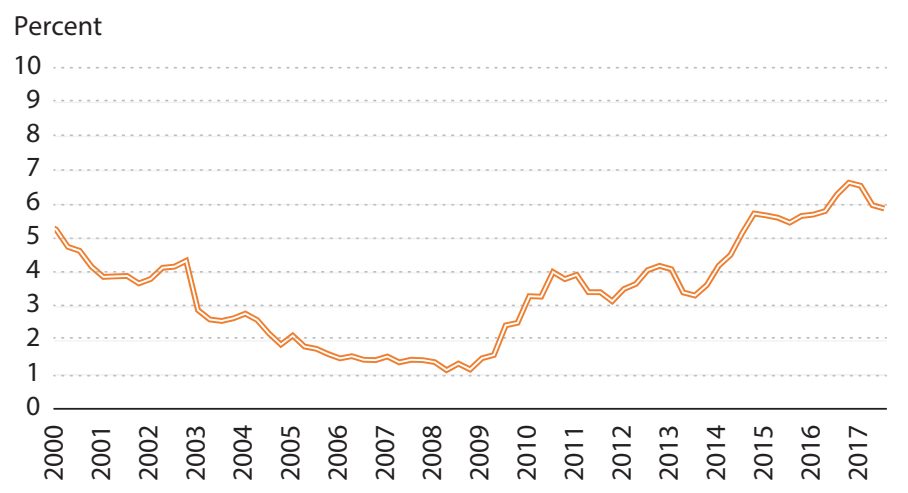

SOURCE: Board of Governors of the Federal Reserve System.

both domestic and foreign markets as investors shifted their portfolios toward the safety of Treasuries. ${ }^{1}$

While the impact of this flight to quality on demand for Treasuries has likely diminished as global financial conditions have stabilized, the safety of Treasuries may continue to attract investment. As shown in Figure 2, European holdings of Treasuries began to rise more rapidly starting in 2007, and they have continued to grow at that pace even after the crisis officially ended. One potential explanation is that investors are holding more Treasuries as part of a flight to quality in the wake of the ongoing European sovereign debt crisis, which began in 2010.

\section{Banking Regulations}

Since the 2007-08 financial crisis, governments have undergone regulatory efforts to keep such a severe crisis from happening again. In 2010, the Dodd-Frank Act was signed into law in the United States, imposing several new stipulations for commercial banks. Primarily, it requires banks to hold a larger portion of high-quality liquid assets than before. Again, Treasuries are among the safest and most liquid assets, making them attractive for banks looking to satisfy their new requirements.

As shown in Figure 3, the ratio of Treasury holdings to private loans for commercial banks was declining until the crisis. However, partly because of Dodd-Frank, this ratio has increased fivefold since the crisis as banks have increased their holdings of Treasuries. Similar international regulations that impose high-quality capital and liquidity requirements, such as Basel III, could have comparable effects on the foreign demand for Treasuries. ${ }^{2}$

More recent regulatory actions have also made Treasuries attractive in what is known as the "shadow banking" sector. ${ }^{3}$ One component of shadow banking is money market funds,
Figure 4

U.S. Money Market Fund Holdings by Fund Type, 2000-17

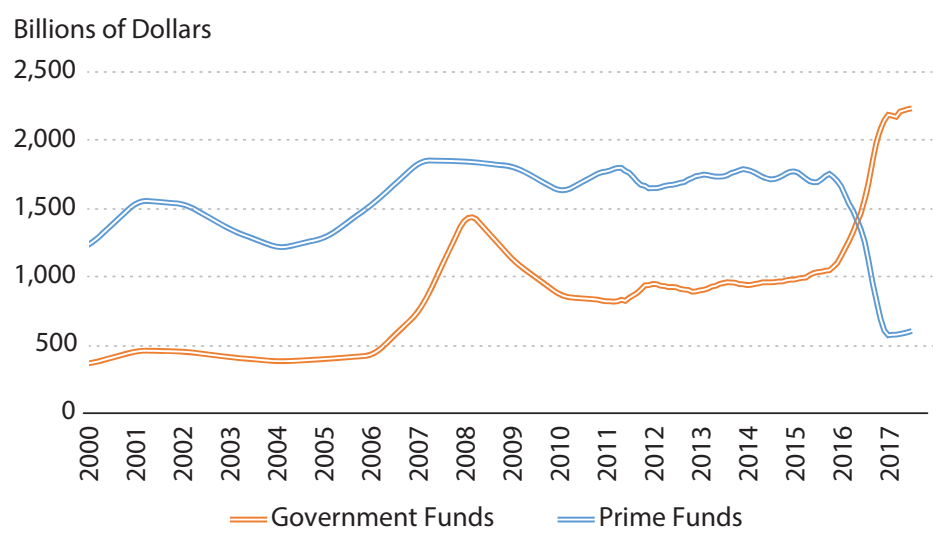

SOURCE: Board of Governors of the Federal Reserve System.

which invest in short-term debt securities and pass through gains to shareholders. "Prime" money market funds invest in private money market instruments such as commercial paper and securities issued by municipalities. As of October 2016, prime money market funds were subject to new regulations that affect pricing of shares and that ultimately have made prime funds less attractive to investors. ${ }^{4}$ These new rules have led to an increase in demand for "government" money market funds, which invest solely in Treasuries and are not subject to the same regulations as prime funds. As shown in Figure 4, investors have replaced prime money market fund investments with government money market fund investments, indirectly raising the demand for Treasuries.

\section{Economic Implications}

What is likely to happen if the demand for Treasuries slows while the supply continues to grow? The Congressional Budget Office ( $\mathrm{CBO}$ ) projects that, assuming no changes in current law, the federal debt will exceed 90 percent of GDP by 2027. In other words, the supply of Treasuries is expected to keep increasing. If that happens, and the demand for Treasuries is constant or falls, it would drive bond prices down and bond yields up.

Some evidence suggests that the growth in demand for Treasuries has already begun to soften. Returning to Figures 1 and 2, foreign holdings have remained more or less constant since 2014, largely because of declining holdings in Japan and China. Likewise, regulation and policy changes such as the Dodd-Frank Act and new rules for prime money market funds may have only transitory effects on the demand for Treasuries. For example, the pace of growth of the ratio of commercial bank Treasury security holdings to private loans has slowed since 2014 (see Figure 3), 
as has the growth of investment in government money market funds since 2017 (Figure 4).

Perhaps most significantly, bond yields have started to rise in recent years. The current yield of 2.9 percent on a 10-year Treasury bond, while low compared with pre-crisis levels, is up from 1.9 percent in January 2015, indicating that prices have indeed fallen.

\section{Conclusion}

The reasons for the increased demand for Treasuries since the 2007-08 financial crisis are multiple and complex, and we have examined only a few in this essay. Among them: During the crisis, investors shifted their portfolios toward Treasuries to protect against risk, but other factors, such as regulation, have continued to raise the demand for Treasuries in the years since. As a result, both in domestic and foreign sectors, Treasuries have become more attractive to investors, helping to explain why bond prices have risen even as the supply of debt has expanded. However, it appears that the growth in demand for Treasuries has slowed down over the past few years. If the supply of debt continues to increase as projected, higher interest rates are likely in the near horizon.

\section{Notes}

1 See Noeth, Bryan J. and Sengupta, Rajdeep. "Flight to Safety and U.S.

Treasury Securities." Regional Economist, July 2010, pp. 18-19; https://www.stlouisfed.org/publications/regional-economist/july-2010/flightto-safety-and-us-treasury-securities.

2 Basel III is a global set of regulatory standards that applies to a large set of countries. Like the Dodd-Frank Act, Basel III requires banks to hold a certain percentage of both high-quality capital and highly liquid capital. It is currently being implemented in phases, with full implementation planned to be completed by 2019 .

3 "Shadow banking" is a broad term for institutions that engage in functions similar to banks but are not subject to the same regulation as banks. For more, see Panckhurst, Paul and Luo, Jun. "Shadow Banking." Bloomberg, January 23, 2018; https://www.bloomberg.com/quicktake/shadow-banking.

${ }^{4}$ See Wheelock, David C. "New SEC Rules Cause Shift in Money Market Fund Assets." On the Economy blog, September 6, 2016;

https://www.stlouisfed.org/on-the-economy/2016/september/new-sec-rulescause-shift-money-market-fund-assets. 